\title{
PERTANGGUNGJAWABAN INDONESIA TERHADAP PENCEMARAN KABUT ASAP DI KAWASAN ASEAN (PENDEKATAN ECONOMIC ANALYSIS OF LAW)
}

\author{
Deni Bram'
}

\begin{abstract}
Abstrak
Haze pollution in the ASEAN region has a result from forest fires in Indonesia has long been on the annual agenda not only for Indonesia but also began familiar to countries - countries in the ASEAN region. The existence of the ASEAN Agreement on Transboundary Haze Pollution as international instruments for overcoming the haze pollution until now has not been taken seriously by the Government of Indonesia as the main actors of the smoke haze pollution in Southeast Asia. This paper will use the approach to economic analysis of law in finding out the background of attitudes and legal actions undertaken by the Government of Indonesia and the impact - the impact is likely to be accepted by the Government of Indonesia with such acts.
\end{abstract}

Kata kunci: pencemaran, lingkungan, ASEAN

\section{Pendahuluan}

Tidak dapat dipungkiri pada perkembangannya, masalah lingkungan hidup semakin besar, meluas dan serius. Persoalannya pun tidak terbatas pada tingkat lokal atau translokal, melainkan regional, nasional, transnasional dan global. Secara fisik, keberadaan sumber daya air dan udara tidak mengenal batas administratif dan politik, sehingga kemungkinan terjadinya pencemaran lintas batas dan segala dampak yang kemungkinan timbul menjadi suatu topik yang dibutuhkan pembahasan mendalam. ${ }^{2}$ Salah satu hal penting yang menjadi pokok pembicaraan pada tataran internasional adalah

1 Pengajar Hukum Lingkungan Fakultas Hukum dan Program Pascasarjana Universitas Pancasila dan Peneliti Pusat Kajian Ilmu Hukum Universitas Pancasila. Alamat kontak: deni_up@yahoo.co.id.

2 Thomas W. Merrill, Golden Rules For Transboundary Pollution, Duke Law Journal, 1997, hal. 1. 
penanganan terhadap pencemaran lingkungan yang bersifat lintas batas negara atau transnasional (transboundary pollution). ${ }^{3}$

Dalam konteks kekinian, isu pencemaran lintas batas negara menjadi salah satu isu yang dibicarakan pada tingkat global pada umumnya dan regional, khususnya Asia Tenggara sekarang ini. Hal ini dilatarbelakangi dengan semakin hebatnya pencemaran udara yang terjadi di kawasan Asia Tenggara hingga ke daratan Australia yang disebabkan oleh kebakaran hebat yang melanda kawasan hutan Indonesia. Kabut asap yang dihasilkan dari kebakaran hutan di Indonesia dari tahun ke tahun makin akrab sebagai agenda tahunan bagi negara tetangga dan hal ini disertai pula dengan dampak ekonomis yang dihasilkan dari kabut asap tersebut.

Fenomena kebakaran hutan sebenarnya bukan sesuatu yang asing bagi Indonesia pada khususnya dan dunia pada umumnya, Brazil dan Mexico adalah contoh dari belahan dunia lain yang tak luput dari kebakaran hutan. Di Indonesia sendiri fenomena kebakaran hutan diawali dengan hebat pada era 1980-an. Pada bencana di era tersebut tercatat paling tidak telah membinasakan sedikitnya 11,7 Juta Hektar yang mayoritas terdiri dari dataran savana, perkebunan kayu dan perkebunan warga. ${ }^{4}$ Dari dampak tersebut secara ekonomis terhitung kerugian yang timbul mencapai Rp 9,1 Milyar. $^{5}$

Pada awal terjadinya kebakaran hutan hebat di Indonesia pada pertengahan tahun 1997, diperkirakan kerugian materiil yang dialami oleh Indonesia, Malaysia, dan Singapura mencapai 4,5 Billion US \$ atau setara dengan Rp 9 Milyar pada saat itu, dan sebagai puncaknya kebakaran hutan yang terjadi, Indonesia pun dinobatkan sebagai pencemar udara terbesar di

3 Penggunaan istilah ini mempunyai kesamaan dengan istilah "transfrontier pollution" yang diadopsi oleh Organization for Economic Cooperation and Development Council dengan pengertian: any intentional or unintentional pollution whose physical origin is subject to, and situated wholly or in part within the area under, the national jurisdiction of one Country and which has effects in the area under the national jurisdiction of another Country. Lihat "Organization for Economic Cooperation and Development: Council Recommendation on Implementing a Regime of Equal Right of Access and NonDiscrimination in Relation to Transfrontier Pollution", Annex, July, 1977.

${ }^{4}$ Hety Herawati, Heru Santoso and Claudio Forner, Forest Fires and climate change in Indonesia Background document for the Southeast Asia kick-off meeting of the project Tropical Forests and Climate Change Adaptation ("TroFCCA"), Bogor, May 29 - 302006.

${ }^{5}$ Fire, Smoke, and Haze The ASEAN Response Strategy, Edited by S. Tahir Qadri Association of Southeast Asian Nations. 
dunia. ${ }^{6}$ Selain itu, dampak yang dihasilkan dari kabut asap kebakaran hutan juga memberikan efek kepada menurunnya kesehatan masyarakat sekitar terutama dampak yang mengakibatkan Infeksi Saluran Pernafasan Akut (ISPA).

Menurut United Nations Developments Programme (UNDP), kabut asap pada tahun 1997 mengakibatkan individu-individu di Asia Tenggara mengalami kerugian 1,4 milyar dolar AS, khususnya biaya terhadap kesehatan jangka pendek. Lebih dari 40.000 orang dirawat karena penyakit pernafasan. Dampak kesehatan jangka panjang terhadap anak-anak dan orang dewasa sedang dihitung. ADB memperkirakan 757 juta ton $\mathrm{CO} 2$ dihasilkan oleh pembakaran hutan antara 1997-1998. jumlah biaya atas kandungan karbon di atmosfer (berdasarkan 7 US\$ per metric ton) dikalkulasikan sebanyak 1.446 milyar US\$.?

Di sisi lain, kabut asap mengakibatkan banyaknya para investor asing takut untuk berinvestasi di Indonesia, Malaysia dan Singapura. Karena dengan adanya kabut asap mengakibatkan banyaknya biaya dan resiko yang harus merka tanggung. Bagi Indonesia kebakaran hutan telah mengakibatkan kerugian ekonomi dari degradasi dan deforestasi hutan di Indonesia berkisar antara 1,62-2,7 miliar dollar AS. $^{8}$ Sektor pariwisata juga menerima imbas yang tidak sedikit dari bencana kabut asap yang terjadi, dari sektor penerbangan dan pariwisata yang meliputi penurunan angka hunian hotel dan biro perjalanan tercatat kerugian mencapai Rp 4,89 miliar. Serta banyak bisnis dan investasi yang batal atau tertunda sebagai suatu dampak ekonomi secara tidak langsung, sebesar Rp 25,69 miliar. $^{9}$ Ditambah lagi dengan biaya yang harus dikeluarkan oleh pemerintah negara setempat untuk melakukan usaha pencemaran dengan pembelian masker yang tidak sedikit. ${ }^{10}$ Dampak

${ }^{6}$ Perkiraan ini dibuat pada bulan Mei 1998 oleh The Singapore based Economy and Environment Programme for Southeasat Asia (EEPSEA) dan World Wide Fund for Nature (WWF); seperti yang termuat dalam Indonesia Fires and Haze of 1997: The Economic Tool, (1998).

7 Asian Environmental Outlook 2001, terdapat dalam situs <http://www.adb.org/ Documents/Books/AEO/2001/aeo2010.asp.html>, diakses pada tanggal 10 November 2009.

8 3rd Dialogue on Transboundary Haze Pollution Organised by the Singapore Institute of International Affairs and Institute of Strategic and International Studies Malaysia, terdapat dalam situs <http:/^www.haze-online.or.id/news.php/ID=200307021 00607.htm>. diakses pada tanggal 10 November 2009.

${ }^{9}$ Hak Pembakaran Hutan, Republika, 30 Agustus 2006. 
tidak langsung lainnya yang dihasilkan dari kebakaran hutan serta asapnya adalah menurunnya kualitas tanaman serta keanekaragaman hayati baik flora maupun fauna yang dimiliki baik oleh pemerintah Indonesia maupun negara tetangga sebagai suatu bentuk efek jangka panjang yang dihasilkan dari suatu bencana yang berkelanjutan.

\section{Kerugian Ekonomis Akibat Kebakaran Hutan}

\begin{tabular}{|l|c|}
\hline \multicolumn{1}{|c|}{ Komponen } & $\begin{array}{c}\text { Kerugian Per Hari } \\
\text { (Milyar Rupiah) }\end{array}$ \\
\hline Kerugian Akibat Pembakaran (Fires) & $\mathbf{1 7 0 , 9 2}$ \\
\hline Kayu & 27,45 \\
\hline Pertanian/Perkebunan & 26,16 \\
\hline Nilai Ekosistem Hutan (Langsung dan Tak Langsung) & 99,11 \\
\hline Keanekaragaman Hayati Lokal & 1,67 \\
\hline Penyerapan Karbon & 15,13 \\
\hline Biaya Pemadaman Kebakaran & 1,40 \\
\hline Kerugian Akibat Asap (Haze) & $\mathbf{5 6 , 2 7}$ \\
\hline Kesehatan & 16,39 \\
\hline Produktivitas & 9,30 \\
\hline Dampak Ekonomi Tak Langsung & 25,69 \\
\hline Pariwisata dan Penerbangan & 4,89 \\
\hline Total Kerugian & $\mathbf{2 2 7 , 1 9}$ \\
\hline
\end{tabular}

Sumber: Greenomics Indonesia, Agustus 2006

Dalam sistem hukum internasional, kondisi yang mengakibatkan suatu negara mengalami kerugian akibat tindakan dari negara lain merupakan suatu bentuk pelanggaran kedaulatan suatu negara. Pada situasi demikian dalam pandangan hukum internasional dinyatakan bahwa terdapat pemberian kewenangan bagi tiap negara untuk dapat menuntut suatu bentuk pertanggungjawaban dari pihak lain dalam hal terjadinya pelanggaran hak suatu negara. hal ini kemudian diperkuat dengan adagium yang dipopulerkan oleh Grotius pada tahun 1646 yang menyatakan, bahwa pada setiap kesalahan internasional mengakibatkan kewajiban untuk mengembalikan kerugian yang terjadi. ${ }^{11}$

${ }^{10}$ Kebakaran Hutan Turunkan Kualitas Lingkungan dan Nilai Ekonomi, Suara Pembaruan, 23 Jánuari 2008.

11 Megan Bradley, "The Conditions of Just Return: State Responsibility and Restitution for Refugees", (United Kingdom: University of Oxford), hal. 3. 
Maraknya kasus-kasus pelanggaran atas hukum internasional yang mengakibatkan injury bagi negara lain mendorong Majelis Umum Persatuan Bangsa Bangsa dan Komisi Hukum Internasional untuk mengadakan pembicaraan khusus yang mencoba untuk merumuskan unsur - unsur suatu negara dapat dituntut pertanggungjawaban atas perbuatan yang merugikan negara lain. Dalam laporan akhir sebagaimana tertuang dalam Draft Articles on Responsibility of States for Internationally Wrongful Acts menentukan bahwa terdapat dua elemen utama yang dapat dijadikan dasar pertanggungjawaban negara, yaitu: ${ }^{12}$

1. Dilakukan oleh atau dapat diatribusikan kepada negara dalam kerangka hukum internasional;

2. Secara nyata merupakan pelanggaran terhadap kewajiban internasional suatu negara.

Dalam konteks penerapan prinsip tanggung jawab negara terhadap pencemaran lingkungan yang bersifat transnasional, negara pencemar berkewajiban untuk melakukan reparasi yang ditujukan kepada negara tercemar yang telah merasakan suatu kerugian baik secara langsung maupun tidak langsung akibat tindakan dari negara pencemar. Pada kasus pencemaran kabut asap yang terjadi di kawasan regional ASEAN yang merupakan akibat dari kebakaran hutan di Indonesia, dampak yang timbul tidak hanya telah memberikan kerugian bagi negara-negara tetangga Indonesia, namun juga telah memberikan dampak kerugian bagi Indonesia. Kondisi demikian tentu akan memberikan distribusi eksternalitas ${ }^{13}$ yang tidak simetris dalam penerapan prinsip tanggung jawab negara yang akan mengakibatkan lemahnya penggunaan instrumen prinsip tanggung jawab negara dalam hukum internasional dalam menangani pencemaran kabut asap di kawasan ASEAN pada umumnya dan pencegahan kebakaran hutan di kawasan Indonesia pada khususnya.

Berawal dari fenomena kebakaran hutan yang hebat melanda kawasan ASEAN pada tahun 1997/1998, para petinggi ASEAN mencoba merumuskan pola penanganan yang efektif dengan mengadakan pertemuan persiapan di

12 International Law Commision Draft Articles on State Responsibility, ILC's 53rd Session, Jenewa, 2001.Art.2.

${ }^{13}$ Eksternalitas kerap kali digunakan untuk menggambarkan suatu dampak yang timbul dari suatu kegiatan ekonomi dari seseorang atau perusahaan tertentu yang memberikan dampak bagi orang atau perusahaan lain tanpa adanya izin atau kompensasi terlebih dahulu. Lihat Charles D Kolstad, "Environmental Economics", (New York: Oxford University Press), hal. 91. 
Hanoi yang mengahasilkan Plan of Action dan Visi ASEAN 2020. Sebagai puncak pertemuan tersebut, para pemimpin ASEAN merumuskan pola penanganan pencemaran kabut asap di Asia Tenggara dalam suatu ASEAN Agreement on Transboundary Haze Pollution (Persetujuan ASEAN tentang Pencemaran Kabut Asap Lintas Batas) yang mengatur pendistribusian tanggung jawab dan penanganan pencemaran kabut asap pada kawasan regional Asia Tenggara. Perjanjian ini ditandatangani oleh 10 Negara peserta ASEAN pada Juni 2002, dan kemudian came into force pada 25 November 2003. ${ }^{14}$

Setelah tiga tahun berjalan, tujuh dari sepuluh negara penandatangan telah melakukan ratifikasi dan harmonisasi dengan peraturan perundangundangan nasional negara peserta setempat. Namun, hal ini menjadi ironis pada saat Indonesia sebagai subyek utama kebakaran hutan yang menjadi penyumbang dominan kabut asap yang dipermasalahkan dalam perjanjian tersebut, justru belum melakukan ratifikasi dengan peraturan perundangundangan nasional hingga saat ini. Keberadaan ASEAN Agreement on Transboundary Haze Pollution seharusnya menguntungkan Pemerintah Indonesia, sehingga tidak ada alasan untuk menunda proses ratifikasi terhadap perjanjian tersebut. Bahkan menurut menurut beberapa ahli hukum internasional, dengan melakukan ratifikasi perjanjian tersebut Indonesia akan terbebas dari pertanggungjawaban negara yang diemban. ${ }^{15}$

Sikap pemerintah Indonesia yang sampai saat ini belum meratifikasi ASEAN Agreement on Transboundary Haze Pollution (Persetujuan ASEAN tentang Pencemaran Kabut Asap Lintas Batas), secara tersirat menunjukkan tidak adanya kesungguhan (due diligence) dari pemerintahan saat ini, terlebih hal ini seakan diperkuat dengan adanya upaya legalisasi terhadap beberapa kegiatan pembakaran hutan secara liar di.beberapa daerah dengan istrumen Peraturan Daerah ${ }^{16}$, sedangkan akibat dari kabut asap yang dihasilkan telah memberikan dampak kerugian materiil dan imateriil bagi negara sekitar.

Pilihan untuk melakukan suatu bentuk penaatan dalam optik economic analysis of law sangat ditentukan oleh rasionalitas dan efisiensi yang terdapat

${ }^{14}$ ASEAN Agreement on Transboundary Haze Pollution, Art. 29.

${ }^{15}$ Pendapat ini dikemukakan oleh Guru Besar Hukum Internasional Fakultas Hukum Universitas Indonesia Prof Hikmahanto Juwana, Lihat Media Indoensia Online, Indonesia belum Ratifikasi Perjanjian ASEAN, terdapat dalam situs <http://www.mediaindo.co.id/ RUBRIK/DEFAULT.ASP?CAT_ID=33>.

${ }^{16}$ Peraturan tersebut tercantum dalam Peraturan Daerah Riau dan Peraturan Daerah Kotawaringin Barat. Lihat Deni Bram, Kebijakan Pengelolaan Hutan Belum Proekologi, Media Indonesia, (1 September 2007), hal. 7. 
di setiap tindakan hukum yang akan diambil. Tulisan ini akan mencoba untuk melakukan analisa pendekatan ekonomi atas hukum terhadap sikap Pemerintah Indonesia yang hingga saat ini enggan untuk melakukan proses ratifikasi terhadap ASEAN Agreement on Transboundary Haze Pollution (Persetujuan ASEAN tentang Pencemaran Kabut Asap Lintas Batas) serta prediksi untung - rugi yang kemungkinan di derita oleh Pemerintah Indonesia dalam mengambil suatu tindakan hukum.

\section{Pembahasan}

Ekonomi adalah suatu studi tentang tingkah laku yang rasional dalam menghadapi kelangkaan (scarcity). Oleh karena itu, ekonomi dan hukum tidak dapat dipisahkan. Sistem hukum juga berhadapan dengan kelangkaan. Jika semua hal telah sempurna dan baik, maka mungkin tidak perlu lagi ada hukum, tidak perlu ada negara, hidup mungkin jenuh dan membosankan. ${ }^{17}$ Pembicaraan tentang disiplin ilmu ekonomi menurut sebagian orang pada awalnya hanya bicara pada tataran inflasi, lingkaran bisnis dan fenomena ekonomi makro lainnya yang secara umum berbeda dengan isu hukum pada umumnya. Namun sebenarnya, pembicaraan mengenai aspek ekonomi lebih luas dari pandangan tersebut. Pembicaraan mengenai kegiatan ekonomi mencakup pula kegiatan-kegiatan yang berkaitan dengan kehidupan manusia sehari-hari. ${ }^{18}$

Seperti ekonomi, sistem hukum juga adalah mengenai tingkah laku yang rasional. Hukum ingin mempengaruhi sesuatu melalui sanksi, seperti hukuman penjara dan ganti rugi. Aspek yang memaksa dari hukum mengasumsikan bahwa orang tahu mengenai konsekuensinya. Kewajiban hukum tak lain dari prediksi bahwa jika seseorang berbuat atau menghindarkan sesuatu ia akan mengalami penderitaan atau kesusahan, umpamanya, akibat putusan pengadilan. Legislator dan hakim percaya bahwa orang akan menjawab ancaman tersebut dengan memodifikasi tingkah lakunya untuk meminimalkan ongkos dari ketaatan dan sanksi. Negara, dalam bagiannya mencoba meminimalkan ongkos dari pelaksanaan. Dunia sarjana ekonomi mulai dengan perdagangan bebas dan dunia sarjana hukum mulai dengan peraturan, dua disiplin ini melahirkan different prescriptions

${ }^{17}$ Erman Rajagukguk, Kontrak Bisnis Internasional dan Kaitannya dengan Analisis Ekonomi terhadap Kontrak, Jurnal Magister Hukum UII, Vol. 1 No. I September 1999, hal. 6. 1998), hal. 1.

${ }^{18}$ Richard Posner, "Economic Analysis of Law", (Kluwer: Aspen Law and Business, 
mengenai interaksi sosial. Dari ide dan pemahaman ini, kini muncul konsep analisis ekonomi terhadap hukum. ${ }^{19}$

Dalam berbagai bentuk penanggulangan permasalahan di bidang lingkungan hidup, berbagai pendekatan dilakukan dalam rangka memberikan hasil yang maksimal dan mengembalikan fungsi lingkungan hidup seperti semula. Salah satu bentuk perhatian utama dalam rangka menanggulangi permasalahan lingkungan hidup pada tingkat internasional adalah menetapkan dan melaksanakan prinsip - prinsip hukum lingkungan internasional seperti prinsip pembangunan berkelanjutan, prinsip pencegahan dini dan prinsip tanggung jawab negara sebagai suatu bentuk panduan dalam hukum lingkungan internasional. ${ }^{20}$

Salah bentuk pendekatan yang dapat dilakukan dalam melihat keberadaan suatu peraturan dalam rangka menanggulangi permasalahan lingkungan adalah dengan menggunakan pendekatan ekonomi lingkungan yang memberikan pendekatan ekonomi terhadap regulasi penanggulangan lingkungan hidup. Pendekatan ini memfokuskan pada penilaian terhadap dampak ekonomi yang timbul dari suatu peraturan tertentu, termasuk di dalamnya penilaian dengan menggunakan pendekatan cost benefit analysis. ${ }^{21}$

Pendekatan analisa ekonomi terhadap hukum yang salah satunya dipelopori oleh Richard Posner yang dituangkan dalam salah satu karya monumenalnya Economic Analysis of Law mengatakan bahwa pada konsep tradisional pendekatan ekonomi terhadap hukum keberadaan pendekatan ekonomi hanya terbatas pada bidang hukum yang berkaitan secara langsung berkaitan dengan bidang ekonomi seperti hukum anti monopoli, hukum pajak, hukum tenaga kerja. Pada konsep analisa ekonomi terhadap hukum dalam konsep ini terdapat penggunaan istilah yang harus didefinisikan sebagai instrumen yang membantu dalam melakukan analisis seperti pendefinisian terminologi pasar, biaya, keuntungan serta efisien. ${ }^{22}$

Namun kini dengan dipelopori oleh Guido Calebresi dan Ronald Coase, metode pendekatan ekonomi terhadap hukum juga dapat diterapkan ke bidang terapan ilmu hukum lainnya seperti hukum pidana, hukum

${ }^{19}$ Frank H. Easterbrook, The Inevitability of Law and Economic, Legal Education Review, Vol. 1 No. 1, 1989, hal. 3-4.

${ }^{20}$ Edward Elger, "The Economics Analysis of Environmental Policy and Law", (United Kingdom: Edward Elgar Publishing Limited), hal. 1.

${ }^{21}$ Ibid.

22 Jason N E Varuhas, "The Economic Analysis Of Law In New Zealand", New Zealand Institute for the Study of Competition and Regulation October 2005, hal. 8. 
keluarga, hukum konstitusi, hukum internasional dan juga hukum lingkungan. Pendekatan yang seringkali diistilahkan penggunaan economic analysis of law terhadap new law ini mencoba untuk menerapkan analisa ekonomi secara sistematis kepada cabang ilmu hukum yang tidak mempunyai kaitan secara langsung dengan ekonomi. ${ }^{23}$

Dalam konsep ekonomi, mekanisme pasar yang selalu di agungagungkan tidaklah selalu memberikan keuntungan yang simetris. Dalam melihat adanya pertentangan antara kepentingan ekonomi dan ekologi dalam pemenuhan kebutuhan manusia, pendekatan environmental economics dilakukan baik dengan instrumen pendekatan secara positive maupun normative. Pendekatan positif dalam ekonomi melihat keberadaan suatu pasar yang bebas nilai dan terbentuk sendirinya dengan mekanisme pasar. Sedangkan pendekatan normatif menekankan pada adanya kebijakan pemerintah untuk mewujudkan keadilan environmental economics. ${ }^{24}$

Ekonomi dan lingkungan dalam berbagai pendapat para ahli seringkali dianggap sebagai dua sisi yang selalu berada dalam posisi yang berseberangan. Teringat salah satu tonggak perkembangan hukum lingkungan yang mulai timbul didorong oleh kesadaran pada tingkat global terhadap berbagai kerusakan lingkungan hidup dan sumber daya alam yang semakin meningkat dan justru bersumber dari dampak perbuatan manusia dalam memenuhi kebutuhannya, terlebih setelah lahirnya era industrialisasi. Dilihat dari realita yang ada, sepertinya tidak berlebihan jika E Sumacher menyimpulkan bahwa masyarakat yang menganggap dirinya modern akan meletakkan dirinya sebagai entitas yang terpisah dari alam, sehingga motif motif yang tercipta adalah lebih untuk menguasai dan melakukan dominasi kepada alam. ${ }^{25}$

Pendekatan ekonomi terhadap hukum sebagaimana diungkapkan di atas menjadi sangat menarik untuk mengetahui rasionalitas dari sikap Pemerintah Indonesia yang hingga kini masih enggan untuk melakukan ratifikasi terhadap ASEAN Agreement on Transboundary Haze Pollution (Persetujuan ASEAN tentang Pencemaran Kabut Asap Lintas Batas) yang notabene mendudukkan Indonesia sebagai pemeran utama untuk diatur tindak tanduknya sebagai negara yang menyebabkan pencemaran kabut asap.

${ }^{23}$ Richard Posner, Loc. Cit., hal. 25.

${ }^{24}$ Charles Kolstad, "Environmental Economics", (New York: Oxford University Press, 2000), hal.7.

25 Ibid., hal. 11 
Dalam tataran regional, kawasan Asia Tenggara dan belahan Amerika Selatan menjadi tempat yang sangat rentan dengan masalah kebakaran hutan yang terjadi. ${ }^{26}$ Sebagai bentuk tindak lanjut dari maraknya kebakaran hutan khususnya di Asia Tenggara dan dampak kabut asap yang dihasilkan, negara - negara yang tergabung dalam Association of South East Asian Nations (ASEAN) mencoba untuk merumuskan suatu kebijakan terkait dengan penanggulangan kebakaran hutan di Asia Tenggara. Pembicaraan mengenai dampak kabut asap akibat kebakaran hutan sebenarnya telah dimulai pada tahun 1992 dengan mengadakan pertemuan di Bandung. ${ }^{27}$

Konferensi Bandung menghasilkan pembicaraan pada tingkat mentri untuk melakukan suatu penanganan secara sesegera mungkin dan merumuskan suatu kebijakan secara bersama - sama dalam rangka pengendalian asap yang dituangkan dalam dokumen "Long-Term, Integrated Forest Fire Management Programme". ${ }^{28}$ Pertemuan juga dilakukan pada tahun yang sama tepatnya 27 dan 28 Januari 1992 di Singapura. Dalam pertemuan pada tingkat kepala Pemerintahan ini para negara anggota sepakat untuk meningkatkan kerjasama di bidang lingkungan hidup, khususnya dalam hal pencemaran transnasional, bencana alam, kebakaran hutan, dan pemberantasan illegal logging. ${ }^{29}$

Pada tanggal 26 April 1994, pertemuan selanjutnya diadakan di bandar Sri Begawan yang melibatkan para Mentri Lingkungan negara-negara anggota ASEAN yang menghasilkan rencana kerja berupa tindak lanjut dari Agenda 21 pada regional ASEAN. Untuk mempermudah langkah yang ingin dilaksanakan, pembicaraan difokuskan pada 3 (tiga) isu utama yang meliputi: (i) Pencemaran Atmosfir Lintas Batas; (ii) Pencemaran Limbah Berbahaya Lintas Batas dan; (iii) Pencemaran Lintas Batas akibat limbah Kapal Laut. ${ }^{30}$

Pada pertemuan selanjutnya yang diadakan pada bulan Juni tahun 1995, para menteri di negara-negara ASEAN sepakat untuk membuat Rencana Kerjasama terhadap Pencemaran Transnasional (Lintas Batas). ${ }^{31}$

${ }^{26}$ Niko Price, Fiery Crisis in Mexico Forest Preserve Threatened Haze Blowing Into U.S., Record, June 6, 1998, hal. A10.

27 Johan G. Goldammer, Sing. Envtl. Council, "Scientific and Technical Cooperation in SE Asia", Int'l Contributions (1998), hal. 5.

${ }^{28}$ Ibid., hal. 2.

${ }^{29} \mathrm{KL}$ Koh, "Selected ASEAN Document on the Environment", (Asia-Pacific Centre for Environmental Law, 1996)., hal. 233.

${ }^{30}$ Ibid. 
Rencana kerjasama tersebut bertujuan untuk membuat suatu kebijakan pada tingkat regional dalam mengatasi akibat kabut asap yang telah mencapai pada hampir setiap wilayah teritorial negara anggota ASEAN. Setiap negara anggota yang turut serta dalam rencana kerjasama ini sepakat untuk saling bertukar informasi dan mengadakan pengalihan teknologi dalam rangka meminimalisir potensi kebakaran hutan. ${ }^{32}$

Walaupun keberadaan rencana kerjasama untuk menanggulangi kebakaran hutan dan kabut asap yang dihasilkan sekilas memiliki keunggulan dibandingkan dengan perjanjian-perjanjian sejenis pada tingkat regional lainnya, ${ }^{33}$ akan tetapi secara umum dapat dikatakan bahwa rencana yang ada gagal pada tahapan implementasi. Hal ini dilatarbelakangi oleh kurang berminatnya para negara-negara anggota ASEAN lainnya (selain Singapura dan Malaysia) dalam membantu upaya penanggulangan kabut asap karena tidak mengalami dampaknya secara langsung. ${ }^{34}$

Usaha ini pun dilanjutkan kembali dengan membawa isu yang lebih spesifik, yaitu penanggulangan dampak kabut asap melalui pernyataan para menteri yang terkait masing-masing negara anggota ASEAN dalam Regional Haze Action Plan. ${ }^{35}$ Sekali lagi action plan ini mencoba untuk menegaskan secara langsung mengenai dampak kabut asap yang dapat mengganggu tidak hanya ekosistem yang ada, melainkan juga mahluk hidup di dalamnya. Sebagai usaha untuk memanfaatkan momentum yang ada, dalam rencana

${ }^{31}$ Forward to ASEAN Secretariat, ASEAN Cooperation Plan on Transboundary Pollution (1997).

32 ASEAN Cooperation Plan on Transboundary Pollution, terdapat dalam situs $<$ http://www.aseansec.org/function/env/plan.htm>, diakses tanggal 23 Maret 2008.

33 Rencana Kerjasama pada tingkat Regional ASEAN mempunyai keunggulan dimana memuat ketentuan-ketentuan pada tataran praktis. Hal ini dapat dilihat dari berbagai ketentuan dalam Rencana Kerjasama tersebut, yaitu (i) Adanya pembedaan perlakuan bagi ekosistem masing-masing negara dengan memperhatikan kondisi geografis dan demografi masing-masing negara; (ii) Adanya pengakuan mengenai pentingnya komitmen bersama untuk melakukan penanggulangan kebakaran hutan dan dampak yang dihasilkan, sehingga tidak hanya terpaku pada negara yang menjadi penyumbang pencemaran semata. Lihat Charles Barber, The Case Study Of Indonesia: Environmental Scarcities, State Capacity, Civil Violence 47. Lihat Juga Government Of Indonesia, Indonesia Forestry Action Programme, hal. 9.

${ }^{34}$ First Informal ASEAN Ministerial Meeting on the Environment, Oct. 21, 1994 (), terdapat dalam situs <http://www.aseansec.org/function/infenv1.htm>, diakses pada tanggal 20 Marer 2008.

35 Regional Haze Action Plan, ASEAN, (Dec. 1997) terdapat dalam situs $<$ http://www.aseansec.org/function/pa_haze.html>, diakses pada tanggal 20 Maret 2008. 
kerja ini langsung berusaha untuk membentuk badan penanggulangan kabut asap dan lembaga penelitian pada tingkat regional dan sub regional. ${ }^{36}$

Momentum selanjutnya adalah pada usaha negara-negara nggota ASEAN untuk merumuskan suatu panduan dan komitmen hukum secara bersama-sama yang dituangkan dalam suatu perjanjian yang berjudul ASEAN Agreement on Transboundary Haze Pollution (Persetujuan ASEAN tentang Pencemaran Kabut Asap Lintas Batas) yang mengatur pendistribusian tanggung jawab dan penanganan pencemaran kabut asap pada kawasan regional Asia Tenggara. Perjanjian ini ditandatangani oleh 10 Negara peserta ASEAN pada Juni 2002, dan kemudian came into force pada 25 November $2003 .{ }^{37}$ Setelah tiga tahun berjalan, tujuh dari sepuluh negara penandatangan telah melakukan ratifikasi dan harmonisasi dengan peraturan perundang - undangan nasional negara peserta setempat. ${ }^{38}$

Perjanjian ini mengatur perihal utama dalam penanganan kebakaran hutan pada umumnya dan dampak kabut asap pada khususnya. Perjanjian ini memandatkan untuk dibuat adanya suatu komite ${ }^{39}$ dan lembaga monitoring ${ }^{40}$ untuk mengawasi jalannya isi perjanjian dan menghendaki adanya focal point di masing-masing negara untuk memudahkan proses korespondensi. ${ }^{41}$

Dalam perjanjian ini pula diatur mengenai dasar penilaian ${ }^{42}$ yang dilakukan dalam pencegahan dampak kebakaran hutan dan kabut asap yang dihasilkan baik berupa kebijakan yang merujuk pada ketentuan zero burning

36 Badan Penanggulangan Kabut Asap ini ikut mengambil bagian pada saat kebakaran hutan di Indonesia pada tahun 1998, sedangkan Badan Penelitian mengambil lokasi di Kalimantan dan Riau sebagai pusat penelitian. Lihat Joint Press Statement, Third ASEAN Ministerial Meeting on Haze, para. 8, ASEAN, terdapat dalam situs, <http://www.aseansec. org/function/prhaze3.htm>, diakses 20 Maret 2008.

${ }^{37}$ ASEAN Agreement on Transboundary Haze Pollution, Art. 29.

${ }^{38}$ Negara yang melakukan persetujuan meliputi seluruh negara anggota ASEAN. Sampai dengan Agustus 2005 tercatat yang telah melakukan ratifikasi adalah: (i) Brunei Darussalam tanggal 27 February 2003; (ii) Laos tanggal 19 Desember 2004; (iii) Malaysia tanggal 3 Desember 2002; (iv) Myanmar tanggal 5 Maret 2004; (v) Singapura tanggal 13 Januari 2003; (vi) Thailand tanggal 10 September 2003; (vii) Vietnam tanggal 24 Maret 2003. Lihat ASEAN Agreement on Transboundary Haze Pollution, June 10, 2002, terdapat dalam situs < http://www.aseansec.org/pdf/agr_haze>, diakses tanggal 20 Maret 2008.

${ }^{39}$ ASEAN Agreement on Transboundary Haze Pollution, Art. 5(3).

${ }^{40}$ Ibid., Art.6.

${ }^{41}$ Ibid., Art 7.

${ }^{42}$ Ibid., Art. 8 . 
policy dan mengambil tindakan administratif dan hukum dalam upaya meminimalisir terjadinya kebakaran hutan baik pada tingkat masyarakat tradisional maupun pada industri modern. ${ }^{43}$ Dalam langkah represif perjanjian ini juga menerapkan kesiapsiagaan ${ }^{44}$ dan tanggap darurat ${ }^{45}$ dengan prosedur yang telah dibakukan sebagai bentuk penanganan yang komprehensif dengan mengandalkan peralatan dan teknologi dari penelitian yang dikembangkan. ${ }^{46}$

Persetujuan ASEAN tentang Pencemaran Kabut Asap Lintas Batas mempunyai keterkaitan yang sangat dalam dengan usaha pada tingkat global dalam rangka menciptakan lingkungan hidup yang sehat dan habitable. Salah satu perjanjian internasional yang terkait dengan persetujuan ini adalah Konvensi tentang Pencemaran Udara Lintas Batas Jarak Jauh (Convention on Long-Range Transboundary Air Pollution) sebagai dasar hukum internasional yang mengatur terjadinya pencemaran udara yang secara fisik dari satu negara ke negara lain. Konvensi lain yang terkait adalah Konvensi tentang Perubahan Iklim (Convention on Climate Change) yang bertujuan untuk menstabilkan konsentrasi gas rumah kaca di atmosfir yang dapat membahayakan sistem iklim.

Hal ini tidak terlepas dari sumbangsih hutan Indonesia yang mampu menyerap sebanyak 1500 Megaton emisi CO2, padahal emisi yang dihasilkan oleh hutan Indonesia sendiri hanya 740 Megaton. ${ }^{47}$ Selain itu Persetujuan ASEAN tentang Pencemaran Kabut Asap Lintas Batas berkaitan pula dengan Konvensi tentang Keanekaragaman hayati (Convention on Biological Diversity), mengingat begitu banyaknya keragaman sumber daya baik hayati dan nabati yang tersimpan dalam ekosistem hutan terutama di Indonesia yang terkait satu sama lain dalam rantaian food chain yang terintegratif di dalamnya.

Kondisi Indonesia yang hingga kini belum melakukan ratifikasi dari optik ekonomi paling tidak dapat ditelusuri dilandasi oleh rasionalitas untuk melakukan suatu penaatan maka biaya yang akan timbul jauh lebih besar

$$
\begin{aligned}
& { }^{43} \text { Ibid., Art.9. } \\
& { }^{44} \text { Ibid., Art.10. } \\
& { }^{45} \text { Ibid., Art.11. } \\
& { }^{46} \text { Ibid., Art.12. }
\end{aligned}
$$

47 Kementerian Negara Lingkungan Hidup, "Persetujuan ASEAN tentang Pencemaran Asap Lintas Batas", (Jakarta: Kementerian Negara Lingkungan Hidup, 2003), hal. 10. 
dibandingkan dengan sikap untuk tidak melakukan penaatan. Konsekuensi ekonomis yaitu adanya pendanaan ( fund) yang harus ditanggung oleh setiap negara anggota yang telah meratifikasi ASEAN Agreement on Transboundary Haze Pollution (Persetujuan ASEAN tentang Pencemaran Kabut Asap Lintas Batas) menjadi variabel pertimbangan tersendiri untuk tidak melakukan ratifikasi.

Perspektif Pemerintah Indonesia tentu akan melihat bahwa kondisi saat ini dengan terjadinya fenomena kebakaran hutan yang hampir setiap tahun terjadi lalu langkah penanggulangan yang ditempuh akan memakan biaya yang jauh lebih rendah dibandingkan dengan iuran yang harus dibayar sebagai bentuk konsekuensi dari ratifikasi ASEAN Agreement on Transboundary Haze Pollution (Persetujuan ASEAN tentang Pencemaran Kabut Asap Lintas Batas).

Lemahnya kemungkinan penerapan prinsip tanggung jawab negara yang mempunyai kemungkinan kecil untuk dapat diterapkan kepada Pemerintah Indonesia pun memberikan kontribusi tersendiri dalam mempengaruhi rasionalitas Pemerintah Indonesia dalam memperhitungkan untung - rugi atas sikap yang akan diambil sehubungan dengan proses ratifikasi ASEAN Agreement on Transboundary Haze Pollution (Persetujuan ASĘAN tentang Pencemaran Kabut Asap Lintas Batas).

Memperhatikan yurisprudensi kasus-kasus pencemaran lintas batas negara yang selama ini pernah diadili di International Court of Justice dengan menggunakan delik Tanggung Jawab Negara, unsur pertanggungjawaban yang dituduhkan harus disandarkan pada suatu bentuk kesalahan secara nyata oleh suatu negara. Kondisi regulasi Indonesia yang merumuskan ketentuan secara normatif untuk pelarangan kegiatan pembakaran hutan baik yang terdapat dalam tingkatan Undang Undang Kehutanan maupun dalam Peraturan Pemerintah Nomor 4 Tahun 2001 tentang Pengendalian Kerusakan Dan Atau Pencemaran Lingkungan Hidup Yang Berkaitan Dengan Kebakaran Hutan Dan Atau Lahan telah menjadi alasan penggugur kewajiban Pemerintah Indonesia dalam menanggung pertanggungjawaban kerugian yang timbul akibat kebakaran hutan di kawasan ASEAN.

Semakin kecilnya kemungkinan Pemerintah Indonesia untuk dipersalahkan dengan konsep tanggung jawab negara yang berarti pula kecilnya kemungkinan Pemerintah Indonesia untuk menanggung ganti kerugian terhadap semua dampak yang muncul akibat kebakaran hutan di Indonesia, semakin membuat Pemerintah Indonesia nyaman untuk tetap tidak melakukan proses ratifikasi terhadap ASEAN Agreement on Transboundary Haze Pollution (Persetujuan ASEAN tentang Pencemaran Kabut Asap Lintas Batas). 
Kedua kondisi di atas semakin memperkokoh sikap Pemerintah Indonesia untuk tidak melakukan penaatan terhadap instrumen hukum internasional. Premis pendekatan ekonomi yang menyatakan bahwa suatu kepatuhan akan terjadi pada saat terdapat perpaduan antara efisiensi dan tidak terdapatnya alternatif lain yang memberikan peluang untuk meminimalisasi biaya dalam konteks pencemaran kabut asap di Asia Tenggara akibat kebakaran hutan di Indonesia menjadi sangat beralasan.

\section{Penutup}

Kondisi kebakaran hutan di Indonesia hadir sebagai suatu bentuk pencemaran yang tidak hanya mempunyai dampak pada skala lokal ataupun nasional semata, namun telah bereskalasi menjadi pencemaran yang bersifat transnasional. Pencemaran kabut asap yang terjadi akibat kebakaran hutan di Indonesia tentu tidak hanya memberikan dampak ekologis semata, namun berbagai dampak ekonomis dan medis menjadi turunan yang tidak dapat dielakkan. Keberadaan Indonesia dalam ASEAN Agreement on Transboundary Haze Pollution (Persetujuan ASEAN tentang Pencemaran Kabut Asap Lintas Batas) jelas mempunyai peran penting, kondisi Indonesia yang hingga saat ini belum melakukan ratifikasi terhadap ASEAN Agreement on Transboundary Haze Pollution (Persetujuan ASEAN tentang Pencemaran Kabut Asap Lintas Batas) kiranya perlu dicermati dalam sudut pandang Economic Analysis of Law untuk memperkaya khasanah pemikiran dan mencari alasan rasionalitas tindakan tersebut. Konsep analisa pendekatan ekonomi baik pada tataran normatif yang mencoba mengkritisi dari sudut pandang ekonomi maupun positif dalam bentuk kritik korektif dengan entry point ekonomi ini paling tidak dapat memberikan sumbangsih dalam pembentukan peraturan baik pada tataran lokal, nasional, regional maupun internasional. 


\section{Daftar Pustaka}

\section{Buku}

Adolf, Huala. Aspek-Aspek Negara dalam Hukum Internasional, Jakarta: Raja Grafindo Persada, 1991.

Agustina, Rosa. Perbuatan Melawan Hukum. Jakarta: Pasca Sarjana Fakultas Hukum Universitas Indonesia, 2003.

Akehurst, Michael. A Midern Introduction to International Law, London: George Allen and Unwin, 1982.

Bell, Stuart \& Donald McGillivray. Environmental Law, London: Blackstone Press, 2001.

Birinie, W Patricia and Alan E Boyle. International Law and the Environment., Oxford: Clarendon Press, 1992.

Bradley, Megan. The Conditions of Just Return: State Responsibility and Restitution for Refugees, United Kingdom: University of Oxford, 2007.

Dales, J.H. Pollution Property \& Prices, Toronto: University of Toronto Press, 1986.

Danusaputro, St Munadjat, Hukum Lingkungan, Buku I. Bandung: Binacipta, 1982.

Dixon, Martin. Cases and Material on Internaional Law, New York: Oxford University Press, 2003.

Earthscan, Cropland or Wasteland: The Problems and Promises of Irrigation, London : Earthscan, 1984.

Eckholm, Eric. Down to Earth, New York: WW Norton, 1982.

Harris, David J Cases and Materials on International Law, London: Sweet and Maxwell, 1983.

Hardjasoemantri, Koesnadi. Hukum Tata Lingkungan, Cet.19, Yogyakarta: UGM Press, 2006.

Istanto, F. Sugeng. Hukum Internasional, Yogyakarta: Universitas Atma jaya, 1998. 
Jackson, Robert H. Quasi States: Sovereignity, International Relations, and The Third World, Cambridge: Press Syndicate of The University of Cambridge, 1990.

Johnston, R.J. Nature, State, and Economy: A Political Economy of the Environment, New York: John Willy \& Sons, 1989.

Kamil, Melda, Hukum Internasional hukum yang Hidup. Jakarta: Diadit Media, 2007.

Kolstad, Charles. Environmental Economics. New York: Oxford University Press, 2000.

Lauterpacht, Hersh., A Treatise, Oppenheim's International Law, Vol I, $8^{\text {th }}$ Edition, 1995.

Lillich,Richard B. Development in State Responbility, American Society of International Law Proceedings, 1989.

Merriem,C.E. Jr. History of The Theory of Sovereignty since Rousseau, Kitchener, Ontario: Batoche Books, 1900.

Mills, Kurt. Human Rights in The Emerging Global Order: A New Sovereignty ?. London: MacMillan Press, 1999.

Posner, Richard. Economic Analysis of Law, Kluwer: Aspen Law and Business, 1998.

Potter, Donald W. State Responsibility, Sovereignity, and Failed States, Australia: University of Tasmania, 2005.

Sands, Philipe. Principle of International Environmental Law I, Manchester: Manchester University Press, 1995.

Shaw, Malcom N. International Law, Cambrige:Cambrige University Press, 2003.

\section{Artikel}

Alan Khee, Jin Tan. "Forest Fire of Indonesia: "State Responsibility and Internasional Liability", Singapore: Faculty of Law National University of Singapore, 2005.

Coase, Ronald H. "The Problem of Social Cost", 3 J.L. \& ECON. 1960.

Dorrf, Robert H. "State Failure and Responding to It", New Orleans: Annual Convention on International Studies Association, 2002. 
Mova Al Afghani, Mohammad, "Konsep Kealpaan dalam Hukum Pertanggungjawaban Negara", Makalah yang disampaikan pada saat presentasi Mata Kuliah Hukum Internasional Program Magister Fakultas Hukum Universitas Indonesia, 2005.

Mulyadi, "Permintaan dan Pasokan Kayu di Indonesia", Rimbun, No. 2, 15 Februari.

Posner, Eric. "An Economic Anlysis of State and Individual Responsibility", dalam American Law and Economics Association Review.

Qadri, S. Tahir. "Fire, Smoke, and Haze The ASEAN Response Strategy", 2005 Edited by Association of Southeast Asian Nations.

Refugee Studies Center, "The Condition of Just Return: State Responsiility and Restitution for Refugees", University of Oxford (March, 2005).

Sakumoto, Nauyoki. "The Participatory Forestry Management System in Indonesia", Policy Trend Report, IDE/JETRO, 2002.

\section{Peraturan}

ASEAN Agreement on Transboundary Haze Pollution.

International Law Commission Draft Article on State Responsibility, ILC 2001 Report. 